\title{
Demographic, Clinical, Electrophysiological, and Immunological Features of Patients with Myasthenia Gravis Diagnosed in the Last Five Years
}

\author{
Son 5 Yılda Yeni Tanı Alan Myasthenia Gravis Hastalarımızın Demografik, Klinik, \\ Elektrofizyolojik Özellikleri ile İmmünolojik Parametreleri
}

\begin{abstract}
Objective: This study aimed to analyze the demographic, clinical, electrophysiological, and immunological features of patients with myasthenia gravis (MG) diagnosed at the outpatient clinic of the Department of Neurology, Faculty of Medicine, Ataturk University, between January 2015 and January 2020.

Materials and Methods: The study included 53 patients with MG who were newly diagnosed at the Department of Neurology, Faculty of Medicine, Ataturk University, between January 2015 and January 2020. Patients' files were retrospectively analyzed. The demographic and clinical data, acetyl choline receptor (AChR) antibody level, anti-muscle-specific kinase (anti-MuSK) antibody level, thymoma status, and electrophysiological characteristics were recorded.

Results: Of patients with MG, $28(52.8 \%)$ were female and $25(47.1 \%)$ were male. The average age of onset was $44.1 \pm 17.6$ years in male patients and $32.4 \pm 12.4$ years in female patients. Of the female patients, $53.6 \%$ were aged between 20 and 40 years, and $44 \%$ of the male patients were older than 60 years. Twenty-two (41.3\%) patients had ocular onset MG, and $16(30.1 \%)$ patients had generalized onset MG. AChR antibody was positive in 44 (83\%) patients, and anti-MuSK antibody was positive in three (5.6\%) patients. Eighteen (33.9\%) patients had thymoma, and $10(18.8 \%)$ patients had thymic hyperplasia. In $30(56.6 \%)$ patients, a decremental response was obtained in repetitive nerve stimulation in electromyography.

Conclusion: Our study confirmed that MG occurred at a higher rate in women, at younger ages, and in men older than 60 years. Ocular symptoms were the most common reason for admission. The number of patients with MG with moderate and severe clinical pictures was high. A high rate of anti-AChR antibody positivity was found in patients with ocular MG. The incidence results of timoma was high.
\end{abstract}

Keywords: Myasthenia gravis, acetylcholine receptor antibody, repetitive nerve stimulation, thymoma

Öz

Amaç: Çalışmamızda; Atatürk Üniversitesi Tıp Fakültesi Nöroloji Anabilim Dalı Polikliniği’nde Ocak 2015-Ocak 2020 tarihleri arasında tanı alan myasthenia gravis (MG) hastalarının demografik, klinik, elektrofizyolojik özellikleri ile immünolojik parametrelerini analiz ederek sunmayı amaçladık.

Gereç ve Yöntem: Çalışmaya Atatürk Üniversitesi Tıp Fakültesi Nöroloji Anabilim Dalı Polikliniği’nde Ocak 2015-Ocak 2020 tarihleri arasında yeni tanı alan 53 MG hastası dahil edildi. Hastaların dosyaları retrospektif olarak incelenerek hastaların demografik ve klinik verileri, serolojik test profili, timoma ve elektrofizyolojik özellikleri kayıt edildi.

Bulgular: MG tanısı alan hastaların 28'i $(\% 52,8)$ kadın, 25’i $(\% 47,1)$ erkekti. Ortalama başlangıç yaşı erkek hastalarda 44,1 $\pm 17,6$, kadın hastalarda $32,4 \pm 12,4$ idi. Kadın hastalarınn \%53,6'sı 20-40 yaș arasında, erkek hastaların ise \%44'ü 60 yaș ve üzerindeydi. Hastaların 22'si $(\% 41,3)$ oküler, 16'sı $(\% 30,1)$ jeneralize başlangıçlıydı. Kırk dört (\%83) hastanın asetil kolin reseptör (AChR), $3(\% 5,6)$ hastanın anti muscle-spesifik kinaz antikoru pozitifti. On sekiz $(\% 33,9)$ hastanın timoması, $10(\% 18,8)$ hastanın ise timik hiperplazisi mevcuttu. Otuz $(\% 56,6)$ hastanın elektromiyografisinde ardışık sinir uyarımında dekremental yanıt elde edildi.

Sonuç: Çalışmamız MG'nin kadınlarda daha yüksek oranda ve daha genç yaşlarda, erkeklerde ise 60 yaş üzerinde ortaya çıktığını doğrulamaktaydı. Oküler semptomlar en sık başvuru sebebiydi. Orta ve şiddetli kliniğe sahip MG’li hasta sayımız yüksekti. Oküler MG hastalarımızda yüksek oranda anti-AChR antikoru pozitifliği saptandı ve timoma görülme oranımız yüksekti.

Anahtar Kelimeler: Myasthenia gravis, asetilkolin reseptör antikoru, ardışık sinir uyarımı, timoma

Address for Correspondence/Yazışma Adresi: Recep Yevgi MD, Ataturk University Faculty of Medicine, Department of Neurology, Erzurum, Turkey Phone: +90 4423448817 E-mail: recep_yevgi@yahoo.com ORCID: orcid.org/0000-0002-6586-2635

Received/Gelis Tarihi: 26.04.2021 Accepted/Kabul Tarihi: 13.08.2021

${ }^{\circ}$ Copyright 2021 by Turkish Neurological Society

Turkish Journal of Neurology published by Galenos Publishing House. 


\section{Introduction}

Myasthenia gravis (MG) is the most common disease of the neuromuscular junction. The most important clinical feature of the disease is the various degrees of muscle weakness with fluctuations in the ocular, bulbar, extremity, and respiratory muscles. The muscle weakness results from an antibody-mediated immunological attack on proteins in the postsynaptic membrane of the neuromuscular junction. The main antibodies responsible for $\mathrm{MG}$ are antibodies against the acetylcholine receptor (AChR) and muscle-specific tyrosine kinase (MuSK). Moreover, antibodies against lipoprotein receptor-associated protein 4 (LRP4), titin, ryanodine, collagen $\mathrm{Q}$, and cortactin have been described in MG. Patients with no antibodies were diagnosed with seronegative MG (SNMG). The following tests can be used to diagnose MG: Bedside tests, such as the ice pack test and fatigue test; pharmacological tests using anticholinesterases, such as edrophonium and neostigmine; electrodiagnostic tests, such as repetitive nerve stimulation (RNS) and single fiber electromyography (SFEMG). The thymus gland plays an important role in the pathogenesis of $\mathrm{MG}$.

The diagnosis of MG is based on clinical and neurological examination findings and anamnesis. These findings are supported by pharmacological, electrophysiological, and immunological tests $(1,2)$.

MG is an autoimmune disease with a chronic course, and the treatment and follow-up of patients may vary depending on many factors. In this regard, long-term and detailed patient follow-up is important in patients with MG. In our study, we presented the demographic, clinical, electrophysiological, and immunological features of patients with newly diagnosed MG in the last five years in detail, considering the literature.

\section{Materials and Methods}

Fifty-three patients with newly diagnosed MG at the outpatient clinic of the Neurology Department, Faculty of Medicine, Ataturk University, between January 2015 and January 2020, were included in the study. The patients were diagnosed with MG based on the presence of clinical and neurological findings of MG, detection of elevated antibody levels (anti-AChR or anti-MuSK antibodies), and electrophysiological studies ( $\geq 10 \%$ decremental response in RNS or increased jitter in SFEMG). ELISA method was used to measure anti-AChR and anti-MuSK antibody levels. Other rare antibodies, such as antibodies against LRP 4 and titin, could not be studied due to economic reasons. Patients with the following criteria were diagnosed with SNMG: A clinical history and neurological examination findings compatible with $\mathrm{MG}$, positive neostigmine test, RNS or SFEMG compatible with MG, and negative anti-AChR and anti-MuSK antibodies. RNS was performed on the abductor digiti minimi muscle, and SFEMG was performed on the frontal muscle. The files of the patients were retrospectively examined. The demographic and clinical data of the patients, anti-AChR antibody level, anti-MuSK antibody level, thymic pathology, and electrophysiological features were recorded. When patients with MG were first diagnosed, they were classified according to the Myasthenia Gravis Foundation of America (MGFA) clinical classification (3). Thymic pathology data were based on thorax computed tomography (CT) findings in anti-MuSK-antibody-positive patients and thymus gland histopathology reports in other patients. The Ethics Committee of the Faculty of Medicine, Ataturk University, approved the study under decision number $7 / 56$ on 26.06.2020. Since our study was a retrospective study, patient consent was not obtained.

\section{Statistical Analysis}

Categorical data were expressed as a percentage (\%). The difference between categorical variables was analyzed using the chi-square test. A p value less than 0.05 was considered statistically significant.

\section{Results}

Of the patients with MG, 28 (52.8\%) were female and 25 $(47.1 \%)$ were male. The mean age of onset was $44.1 \pm 17.6$ years in male patients and $32.4 \pm 12.4$ years in female patients. Of the female patients, 53.6\% were aged between 20 and 40 years, and $44 \%$ of the male patients were 60 years old or older (Table 1 ).

At the first admission, ocular symptoms were the most common. There was no statistically significant difference between male and female patients in terms of initial symptoms $(\mathrm{p}>0.05)$ (Table 2).

The highest number of patients belonged to class I, according to the MGFA classification (Table 3). According to MGFA classification, there was no statistically significant difference between male and female patients in terms of disease severity (p>0.05) (Table 3).

The ice test was conducted in 32 patients; of them, $25(78.1 \%)$ patients had a positive response.

The neostigmine test was conducted in 50 patients; of them, $41(82 \%)$ had a positive outcome. Neostigmine test was positive in $12(80 \%)$ of 15 patients with generalized MG, $18(85.7 \%)$ of 21 patients with ocular MG, and all patients with SNMG.

Table 1 . The distribution of patients by age and gender

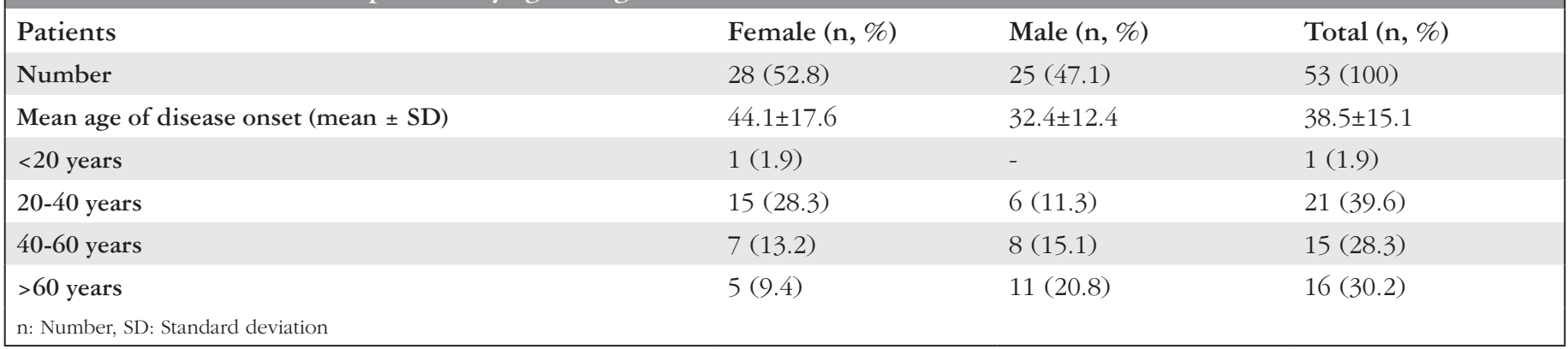


The number of anti-AChR-antibody-positive patients with MG was the highest. Two patients did not want antibody testing due to financial reasons (Table 4).

The rates of obtaining a decremental response in RNS on the electromyography (EMG) and patients' characteristics according to the thymus pathology are shown in Table 5 and 6. Twentythree patients, without a decrement in RNS, underwent SFEMG. Of these patients, $21(91.3 \%)$ had an increase in jitter observed on SFEMG.

Anti-AChR-antibody-positive patients mostly used a combination of pyridostigmine and prednisolone, while antiMuSK-antibody-positive patients mostly used rituximab (Table 7).

\section{Discussion}

MG is a neuromuscular junction disease, characterized clinically by muscle weakness in the form of fatigue and serologically by autoantibodies. The incidence of MG is 7-23 million/year, and its prevalence is between 70 and 320 million/year $(4,5)$. The age distribution in women is bimodal, where the most common age of onset is between 20 and 30 years and over 50 years. In men, the most common age of onset is over 50 years (6). The disease is more common in women than men. In our study, the femaleto-male ratio was $28 / 25$. On analyzing the patients according to age groups, it was noteworthy that women were in the $20-40$ age group (28.3\%), while men were over 60 years old $(20.75 \%)$.

\section{Table 2. The distribution of initial symptoms}

\begin{tabular}{lllll} 
Symptoms & Female $(\%) \mathrm{n}=28$ & Male $(\%) \mathrm{n}=25$ & Total $(\%) \mathrm{n}=53$ & $\mathrm{p}^{*}$ \\
Ocular & $10(18.9)$ & $12(22.6)$ & $22(41.5)$ & 0.531 \\
Generalized & $10(18.9)$ & $6(11.2)$ & $16(30.1)$ & 0.530 \\
Oculobulbar & $4(7.5)$ & $6(11.3)$ & $10(18.8)$ & 0.581 \\
Bulbar & $4(7.5)$ & $1(1.9)$ & $5(9.4)$ & 0.419 \\
"No statistically significant difference was observed between the initial symptoms and genders. n: Number & \\
\hline
\end{tabular}

Table 3. The distribution of patients according to MGFA clinical classification system at the time of the first diagnosis

$\begin{array}{lllll}\text { MGFA clinical classification } & \text { Male }(\%) \mathbf{n}=25 & \text { Female }(\%) \mathbf{n}=28 & \text { Total }(\%) \mathbf{n}=53 & \mathrm{p}^{*} \\ \text { Class I } & 10(18.9) & 12(22.6) & 22(41.5) & 0.945 \\ \text { Class IIa } & 4(7.5) & 5(9.4) & 9(16.9) & 0.851 \\ \text { Class IIb } & 3(5.6) & 3(5.6) & 6(11.2) & 0.774 \\ \text { Class IIIa } & 2(3.7) & 1(1.9) & 3(5.6) & 0.919 \\ \text { Class IIIb } & 2(3.7) & 1(1.9) & 3(5.6) & 0.919 \\ \text { Class IVa } & 1(1.9) & 2(3.7) & 3(5.6) & 0.920 \\ \text { Class IVb } & 1(1.9) & 1(1.9) & 2(3.8) & 0.522 \\ \text { Class V } & 2(3.7) & 3(5.6) & 5(9.3) & 0.894 \\ \text { *According to the MGFA clinical classification system, no statistically significant difference was observed between classes and genders. n: Number, MGFA: Myasthenia } \\ \text { Gravis Foundation of America clinical classification system }\end{array}$

Table 4. Serological test profile

\begin{tabular}{|c|c|c|c|c|}
\hline & Anti-AChR positivity & Anti-MuSK positivity & Seronegative & Unknown antibody result \\
\hline Female (n, \%) & $22(41.5)$ & $2(3.7)$ & $2(3.7)$ & $2(3.7)$ \\
\hline Male (n, \%) & $22(41.5)$ & $1(1.9)$ & $2(3.7)$ & - \\
\hline Generalized MG (n, \%) & $24(77.4)$ & $2(6.45)$ & $3(9.6)$ & $2(6.45)$ \\
\hline Ocular MG (n, \%) & $20(91)$ & $1(4.5)$ & $1(4.5)$ & - \\
\hline
\end{tabular}

Table 5. Repetitive nerve stimulation

\begin{tabular}{lll} 
& Decremental response present & Decremental response absent \\
Female (n, \%) & $18(64.2)$ & $10(35.7)$ \\
Male (n, \%) & $12(48)$ & $13(52)$ \\
Generalized (n, \%) & $20(64.5)$ & $11(35.4)$ \\
Ocular (n, \%) & $10(45.4)$ & $12(54.6)$ \\
n: Number & & \\
\hline
\end{tabular}


In a study with a high number of patients, according to MGFA clinical classification, $26.3 \%$ of the patients were in class I, $50.3 \%$ were in class II, $17.3 \%$ were in class III, $4.6 \%$ were in class IV, and $1.3 \%$ were in class V (7). Clinically, the numbers of patients with moderate and severe MG and those with respiratory muscle weakness, who could be intubated, were high. This may be related to the referral of patients with a more severe disease to our hospital since it is a tertiary care hospital.

Bedside tests such as ice test and fatigue test can be used in the diagnosis of MG. The sensitivity of the ice test has been reported to be approximately $80 \%$ in patients with significant ptosis due to MG $(8,9)$. The rate of significant response to the ice test in our patients was $78.2 \%$, close to the rates mentioned in the literature.

We used neostigmine as a pharmacological test. In a previous study, the sensitivity of the neostigmine test in MG was reported to be $94-100 \%$ for generalized $M G$ and $69-91 \%$ for ocular MG (10,11). Although the sensitivity of the neostigmine test was expected to be higher in generalized MG, in our study, the sensitivity of the neostigmine test was higher in patients with ocular MG. This may have resulted from individual differences in the interpretation of the test.

The most important clinical feature of $M G$ is the various degrees of muscle weakness with fluctuations in the ocular, bulbar, extremity, and respiratory muscles. In different studies, it has been reported that approximately $50 \%$ of the patients present with ocular muscle weakness, $15 \%$ with bulbar muscle weakness, and $5 \%$ with proximal muscle weakness, and they rarely presented with isolated neck, isolated respiratory muscle, or distal muscle weakness $(12,13)$. In our study, on evaluating patients with pure ocular and oculobulbar symptoms together, the rate of ocular symptoms as the initial symptoms was consistent with the literature. Again, when the number of patients presenting with pure bulbar symptoms was evaluated together with the patients presenting with oculobulbar symptoms, it was consistent with the literature.

The main antibodies responsible for MG are anti-AChR, anti-MuSK, and, in rare cases, anti-LRP4 antibodies. It has been reported in various studies that AChR antibody is positive in approximately $80-90 \%$ of patients with generalized MG and $40-55 \%$ of patients with ocular MG (14). In generalized MG, anti-MuSK antibody is found approximately in $7-8 \%$ of the patients and anti-LRP 4 antibody in 1-2\%. 5-6\% of patients with generalized MG are seronegative $(15,16)$. Lennon (17) found that anti-AChR antibodies were positive in $93 \%$ of patients with moderate-to- severe generalized MG, $88 \%$ of patients with mild generalized MG, and $71 \%$ of patients with ocular MG. While the sensitivity of anti-AChR antibody positivity varies according to the type of disease, its specificity is high, 99\% (18). In our study, in patients with generalized MG, anti-AChR antibody positivity rate was consistent with the stated rates. Anti-AChR antibody positivity was detected at a high rate in patients with ocular MG because some patients were excluded from our follow-up over time, so reliable data could not be obtained from their files, and if some of them became generalized later was unknown. In our study, the rates of anti-MuSK antibodies and seronegative patients were in accordance with the rates stated in the literature.

Electrodiagnostic studies are an important complement to immunological studies and may also provide confirmation of MG diagnosis. RNS is positive in $75-80 \%$ of patients with generalized MG and in 30-45\% of patients with ocular MG $(19,20)$. In patients where muscle weakness is severe, such as myasthenic crisis, the sensitivity of this test can be up to $90 \%$. In a previous study, the sensitivity of RNS was $50 \%$ in patients with MG with positive anti-MuSK antibodies (21). The specificity of RNS is around $89 \%$

Table 6. Patients' characteristics according to thymus pathology

\begin{tabular}{|c|c|c|c|}
\hline & Thymoma & Thymic hyperplasia & No thymic pathology \\
\hline Female (n, \%) & $14(50)$ & $3(11)$ & $11(39)$ \\
\hline Male (n, \%) & $4(16)$ & 7 (28) & $14(56)$ \\
\hline Anti-AChR positivity (n, \%) & $18(40.9)$ & $9(20.4)$ & $17(38.6)$ \\
\hline Anti-MuSK positivity (n, \%) & - & $1(33)$ & $2(67)^{*}$ \\
\hline Seronegative (n, \%) & - & - & $4(100)$ \\
\hline
\end{tabular}

Table 7. Treatments of the patients

\begin{tabular}{|c|c|c|c|c|}
\hline Treatment & $\begin{array}{l}\text { Anti-AChR } \\
\text { positivity }\end{array}$ & $\begin{array}{l}\text { Anti-MuSK } \\
\text { positivity }\end{array}$ & Seronegative & $\begin{array}{l}\text { Unknown antibody } \\
\text { result }\end{array}$ \\
\hline Pridostigmine (n, \%) & $3(5.6)$ & - & - & - \\
\hline Prednisolone (n, \%) & $4(7.5)$ & - & - & - \\
\hline Rituximab (n, \%) & - & $2(3.8)$ & - & - \\
\hline Pridostigmine, mycophenolate mofetil (n, \%) & $1(1.9)$ & - & - & - \\
\hline Pridostigmine, prednisolone, monthly IVIG (n, \%) & $4(7.5)$ & - & - & - \\
\hline Pridostigmine, prednisolone (n, \%) & $22(41.5)$ & - & $4(7.5)$ & $2(3.8)$ \\
\hline Pridostigmine, prednisolone, azathioprine (n, \%) & $10(18.9)$ & $1(1.9)$ & - & - \\
\hline
\end{tabular}


(22). According to the literature, our decremental response rates in RNS were considered low in generalized MG and normal in ocular MG. Our results confirmed that the sensitivity of the RNS was higher in MG with more muscle weakness. A decremental response was not observed in RNS in two (67\%) of our three patients with positive anti-MuSK antibody, and it was observed in one $(33.3 \%)$ patient. This result confirmed the low sensitivity of RNS in patients with positive anti-MuSK antibody, although the number of patients was small. Of our four seronegative patients, two $(50 \%)$ were positive for RNS and two (50\%) were negative. An increase in jitter was observed on the SFEMG of two seronegative patients with MG, without a decremental response in RNS.

Approximately $75 \%$ of anti-AChR-antibody-positive patients with MG have thymic abnormalities. In a previous study, the rate of thymic hyperplasia $60-70 \%$, and the rate of thymoma was $10-$ $12 \%$ in these patients (23). In another study, it was stated that $85 \%$ of patients with MG with positive anti-AChR antibodies might have thymic hyperplasia, and up to $15 \%$ might have various thymic tumors, the most common being thymoma (24). In our study, while thymoma rates were high, thymic hyperplasia rates were low. In many reported series, thymomas were more common in males $(25,26)$. In contrast, it was remarkable that thymoma occurred at a higher rate in our female patients, while thymic hyperplasia occurred at a higher rate in our male patients.

Thymic pathology is extremely rare in patients with positive anti-MuSK antibodies. In our study, thymic hyperplasia was observed in one of three patients with positive anti-MuSK antibody. This patient was treated for pneumonia in the chest diseases department of another center eight years before he was diagnosed with MG, and he underwent a surgery after a thymic mass was observed on the thorax CT scan. We believe that this situation may have been detected by chance. The thorax CT scans of the other two anti-MuSK-antibody-positive patients showed no thymic lesions.

In summary, the numbers of patients with moderate-to-severe MG and those who presented with respiratory muscle weakness, which was severe enough to warrant intubation, were high. In our study, the sensitivity of the neostigmine test in patients with generalized MG and the sensitivity of the RNS in anti-MuSKantibody-positive patients were low. A high rate of anti-AChR antibody positivity was detected in patients with ocular MG. Thymoma rates were high, and thymic hyperplasia rates were low.

\section{Conclusion}

Although MG is a disease with a well-known immunopathogenesis, in some patients, problems may be encountered during the followup and treatment. Therefore, in patients with MG, long-term and detailed patient follow-up is important. This study had some limitations as it was a hospital-based study. The lack of data on treatment responses in our study could be given as an example of these limitations. Large-scale epidemiological studies on this subject will be more enlightening.

Ethics

Ethics Committee Approval: The Ethics Committee of the Faculty of Medicine, Ataturk University, approved the study under decision number $7 / 56$ on 26.06.2020.

Informed Consent: Since our study was a retrospective study, patient consent was not obtained.
Peer-review: Externally and internally peer-reviewed.

Financial Disclosure: The author declared that this study received no financial support.

\section{References}

1. Nicolle MW. Myasthenia gravis and lambert-eaton myasthenic syndrome. Continuum (Minneap Minn) 2016;22(6, Muscle and Neuromuscular Junction Disorders):1978-2005.

2. Gilhus NE. Myasthenia gravis. N Engl J Med 2016;375:2570-2581.

3. Jaretzki A 3rd, Barohn RJ, Ernstoff RM, et al. Myasthenia gravis: recommendations for clinical research standards. Task force of the medical scientific advisory board of the myasthenia gravis foundation of America. Ann Thorac Surg 2000;70:327-334.

4. Breiner A, Widdifield J, Katzberg HD, et al. Epidemiology of myasthenia gravis in Ontario, Canada. Neuromuscul Disord 2016;26:41.

5. Carr AS, Cardwell CR, McCarron PO, McConville J. A systematic review of population based epidemiological studies in Myasthenia Gravis. BMC Neurol 2010;10:46.

6. Andersen JB, Heldal AT, Engeland A, Gilhus NE. Myasthenia gravis epidemiology in a national cohort; combining multiple disease registries. Acta Neurol Scand Suppl 2014:26-31.

7. Singhal BS, Bhatia NS, Umesh T, Menon S. Myasthenia gravis: a study from India. Neurol India 2008;56:352-355.

8. Golnik KC, Pena R, Lee AG, Eggenberger ER. An ice test for the diagnosis of myasthenia gravis. Ophthalmology 1999;106:1282-1286.

9. Larner AJ. The place of the ice pack test in the diagnosis of myasthenia gravis. Int J Clin Pract 2004;58:887-888.

10. Pascuzzi RM. The edrophonium test. Semin Neurol 2003;23:83-88.

11. Oosterhuis HJGH. Diagnosis and differential diagnosis. In: Baets $\mathbf{M H}$ de, Oosterhuis HJGH (eds). Myasthenia gravis. Boca Raton: CRC Press, 1993:226.

12. Oosterhuis HJ. The natural course of myasthenia gravis: a long term follow up study. J Neurol Neurosurg Psychiatry 1989;52:1121-1127.

13. Grob D, Brunner N, Namba T, Pagala M. Lifetime course of myasthenia gravis. Muscle Nerve 2008;37:141-149.

14. Vincent A, McConville J, Farrugia ME, et al. Antibodies in myasthenia gravis and related disorders. Ann N Y Acad Sci 2003;998:324-335.

15. McConville J, Farrugia ME, Beeson D, et al. Detection and characterization of MuSK antibodies in seronegative myasthenia gravis. Ann Neurol 2004;55:580-584.

16. Chan $\mathrm{KH}$, Lachance $\mathrm{DH}$, Harper CM, Lennon VA. Frequency of seronegativity in adult-acquired generalized myasthenia gravis. Muscle Nerve 2007;36:651-658.

17. Lennon VA. Serologic profile of myasthenia gravis and distinction from the Lambert-Eaton myasthenic syndrome. Neurology 1997;48(Suppl 5):S23-S27.

18. Leite MI, Waters P, Vincent A. Diagnostic use of autoantibodies in myasthenia gravis. Autoimmunity 2010;43:371-379.

19. Younger DS, Worrall BB, Penn AS. Myasthenia gravis: historical perspective and overview. Neurology 1997;48(Suppl 5):S1-S7.

20. Costa J, Evangelista T, Conceição I, de Carvalho M. Repetitive nerve stimulation in myasthenia gravis--relative sensitivity of different muscles. Clin Neurophysiol 2004;115:2776-2782.

21. Nikolic A, Basta I, Stojanovic VR, Stevic Z, Lavrnic D. Electrophysiological profile of the patients with MuSK positive myasthenia gravis. Neurol Res 2014;36:945-949.

22. Elrod RD, Weinberg DA. Ocular myasthenia gravis. Ophthalmol Clin North Am.2004;17:275-309;v.

23. Gilhus NE. Myasthenia Gravis. N Engl J Med 2016;375:2570-2581.

24. Castleman B. The pathology of the thymus gland in myasthenia gravis. Ann N Y Acad Sci 1966;135:496-505.

25. Maggi G, Casadio C, Cavallo A, et al. Thymectomy in myasthenia gravis. Results of 662 cases operated upon in 15 years. Eur J Cardiothorac Surg 1989;3:504-509; discussion 510-511.

26. Alexiev BA, Drachenberg CB, Burke AP. Thymomas: a cytological and immunohistochemical study, with emphasis on lymphoid and neuroendocrine markers. Diagn Pathol 2007;2:13. 